\title{
Nilai Budaya Tradisi Dieng Culture Festival sebagai Kearifan Lokal untuk Membangun Karakter Bangsa
}

Yuni Harmawati, Aim Abdulkarim, dan Rahmat

Sekolah Pascasarjana Universitas Pendidikan Indonesia, Bandung

Jln. Dr. Setiabudhi, 229 Bandung 40154 Indonesia

Tlp. 082242634246, E-mail: yuniharmawati92@yahoo.co.id

Volume 3 Nomor 2

Oktober 2016: 82-95

\begin{abstract}
ABSTRAK
Penelitian ini bertujuan untuk mengetahui nilai budaya tradisi Dieng Culture Festival yang berperan sebagai kearifan lokal dalam upaya untuk membangun karakter bangsa. Penelitian ini menggunakan pendekatan kualitatif dengan metode studi kasus. Data diperoleh melalui observasi, wawancara, dan dokumentasi. Teknik analisis yang digunakan dalam penelitian ini adalah triangulasi sumber dan triangulasi teknik. Hasil penelitian menunjukkan bahwa: (1) persepsi masyarakat terhadap transformasi nilai budaya tradisi Dieng Culture Festival secara turun-temurun tanpa mengubah makna sebenarnya; (2) adanya relevansi antara kearifan lokal terhadap pembangunan karakter bangsa karena nilai kearifan lokal bukan sebagai hal yang menghambat pada era globalisasi, melainkan menjadi kekuatan besar dalam membangun karakter bangsa.
\end{abstract}

Kata kunci: kearifan lokal, karakter bangsa, Dieng Culture Festival

\begin{abstract}
Cultural Value of "Dieng Culture Festival" Tradition as a Local Wisdom for Building the Nation Character: Case Study at Dieng Plateau. This study aims to know the value of cultural tradition of Dieng Culture Festival which serves as the local wisdom in an effort to build the national character. The research is qualitative with the case study method. The data collection techniques used by researchers include: observation, interviews and documentation. The analysis technique used in this study include: triangulation of sources and triangulation techniques. The results show that: (1) the perception of community about transformation of Dieng Culture Festival without changing the actual meaning; (2) the relevance of local wisdom with the character of the nation.
\end{abstract}

Keywords: local wisdom, national character, Dieng Culture Festival

\section{Pendahuluan}

Bangsa Indonesia sudah sejak lama mempunyai nilai karakter yang tertuang dalam sila pertama sampai kelima Pancasila. Pembangunan bangsa dan karakter harus berjalan beriringan. (Budimansyah, 2010: 1) menyatakan bahwa hal tersebut tersirat dalam syair lagu kebangsaan Indonesia, yaitu "Bangunlah jiwanya bangunlah badannya untuk Indonesia Raya”. Lirik ini berarti dalam membangun bangsa Indonesia yang berkarakter, yang harus dibangun terlebih dahulu adalah jiwanya setelah itu beriringan dengan badan atau raganya. Ki Hadjar Dewantara (Suparlan, 2014: 4) menyatakan bahwa untuk membentuk karakter adalah dengan konsep ngerti, ngroso, lan nglakoni.

Konsep tersebut dimaksudkan agar pembangunan karakter ini melalui tiga tahap, yaitu ngerti yang berarti mengerti akan bagaimana karakter yang baik sesuai dengan nilai budaya bangsa Indonesia. Istilah berikutnya adalah ngroso maksudnya adalah berusaha semaksimal mungkin 
untuk memahami dan merasakan karakter yang sesuai dengan nilai budaya bangsa Indonesia; kemudian nglakoni adalah mengaplikasikan karakter tersebut dalam kehidupan sehari-hari secara berkesinambungan.

Dieng Culture Festival (DCF) merupakan suatu festival yang menyajikan berbagai kesenian tradisional antara lain kuda lumping, tari rampak yakso, wayang, dan diakhiri dengan upacara ritual pemotongan rambut gimbal. Nilai-nilai karakteristik yang terkandung dalam kearifan lokal tersebut diharapkan mampu melekat pada bangsa Indonesia dan menjadi kekuatan besar untuk menjadikan bangsa Indonesia menjadi bangsa yang berkarakter. Bangsa yang berkarakter adalah bangsa yang mampu melewati dampak negatif kedahsyatan globalisasi, yang artinya bangsa yang tetap kokoh walaupun terjadi perubahan atas globalisasi, tidak terpengaruh adanya dampak negatif globalisasi. Nilai-nilai budaya yang dimiliki oleh bangsa Indonesia dalam hal ini belum optimal untuk membangun karakter bangsa. Melunturnya kejujuran, sopan santun, dan rasa gotong royong merupakan ciri-ciri perilaku manusia yang menuju ke arah kehancuran suatu bangsa.

\section{Transformasi Budaya}

Transformasi merupakan pergeseran suatu hal ke arah yang baru tanpa mengubah makna di dalamnya. Transformasi budaya tidak dapat direkayasa ataupun dipaksakan. Transformasi budaya secara pasti dapat mengubah pola pikir dari suatu bangsa. Bangsa yang hebat adalah bangsa yang selalu menjaga nilai tradisinya untuk dijadikan kekuatan menuju bangsa yang maju. Suatu bangsa apabila tidak mau kehilangan jati diri, maka harus diberikan ruang bagi nilai-nilai tradisi untuk tetap berkembang dalam masyarakat.

Fortes (Tilaar, 1999:54) mengemukakan tiga variabel utama dalam transformasi budaya, yaitu (1) unsur-unsur yang ditransformasikan, (2) proses transformasi, dan (3) cara transformasi.

Kebiasaan yang terdapat dalam masyarakat merupakan suatu bukti yang dapat menyatakan bahwa di dalam kehidupan masyarakat terdapat budaya yang mengandung nilai-nilai untuk menunjang tercapainya kepentingan masyarakat. Oleh karena itu, diperlukan suatu usaha transformasi budaya dalam kehidupan masyarakat untuk mempertahankan dan melaksanakan nilainilai budaya tersebut agar dapat dijadikan dasar dalam kehidupan bermasyarakat, berbangsa, dan bernegara. Dpat disimpulkan bahwa transformasi budaya merupakan upaya yang dilakukan untuk memindahkan nilai-nilai yang terkandung di dalam budaya agar masyarakat memiliki karakter yang baik dalam kehidupan bermasyarakat, berbangsa, dan bernegara.

\section{Karakter Bangsa}

Secara umum karakter dimaknai sebagai cara berpikir dan berperilaku yang khas tiap individu untuk hidup dan bekerja sama, baik dalam lingkungan keluarga, masyarakat, maupun bangsa dan negara. Samani dan Hariyanto (2012:41) menyatakan bahwa karakter adalah perilaku yang tampak dalam kehidupan sehari-hari baik dalam bersikap maupun bertindak. Koesoema (2010:79) sementara itu mengartikan karakter sebagai kondisi dinamis struktur antropologis individu, yang tidak mau sekadar berhenti atas determinasi kodratinya, tetapi juga berusaha hidup untuk menjadi semakin integral mengatasi determinasi alam dalam dirinya sendiri sebagai proses penyempurnaan dirinya terus-menerus.

Secara universal berbagai karakter dirumuskan sebagai nilai hidup bersama berdasarkan atas pilar: kedamaian (peace), menghargai (respect), kerja sama (cooperation), kebebasan (freedom), kebahagiaan (happiness), kejujuran (honesty), kerendahan hati (humility), kasih sayang (love), tanggung jawab (responsibility), kesederhanaan (simplicity), toleransi (tolerance), dan persatuan (unity) (Samani dan Hariyanto, 2012:43). Lickona (2013: 51) menyatakan bahwa karakter memiliki tiga komponen yang memiliki relasi kuat di antara ketiganya dalam hubungannya dengan moral antara lain: (1) moral knowing, (2) moral feeling, dan (3) moral action.

Hal ini dapat disimpulkan bahwa karakter merupakan watak yang dapat memengaruhi seluruh tindakan orang yang satu dengan yang 
lain. Karakter merupakan identitas atau jati diri yang menjadi acuan interaksi antarmanusia yang satu dengan yang lain. Karakter bisa berasal dari pembawaan lahir dan pembiasaan dari individu dengan lingkungannya yang dapat dilihat melalui proses sosialisasi dengan individu yang lain. Karakter berasal dari jati diri dan jati diri bersumber dari kepribadian.

Definisi karakter menurut Websters New World Collage Dictionary (Darahim, 2015: 21) adalah "Character is the pattern of behavior or personality found in individual or group; moral constitution; moral strength; self discipline, fortitude, and ect". Karakter merupakan pola hidup, sikap, dan perilaku seorang atau kelompok orang yang sudah baku dan dipergunakan dalam berkomunikasi dengan orang lain. Karakter yang baik adalah karakter yang dilandasi oleh norma, sikap, dan perilaku yang kuat.

Pembangunan karakter bangsa merupakan hal yang penting karena berhubungan dengan proses membina dan memperbaiki perilaku dan nilai luhur yang dijiwai oleh nilai-nilai Pancasila dan UUD 1945. Dengan demikian, dapat terbentuk warga negara yang tangguh, berakhlak mulia, berbudi luhur, bergotong royong, yang dilandasi oleh iman dan takwa kepada Tuhan Yang Maha Esa. Dalam penelitian ini akan difokuskan nilai karakter yang terkandung di dalam tradisi DCF.

\section{Kearifan Lokal untuk Membangun Karakter Bangsa}

Kearifan lokal adalah sebuah pengalaman panjang dan tidak lepas dari lingkungan pemiliknya. Kearifan lokal bersifat dinamis menyesuaikan dengan zaman. Menurut Suardiman (Wagiran, 2012:334), kearifan lokal identik dengan perilaku manusia berhubungan dengan: (1) Tuhan, (2) tanda-tanda alam, (3) lingkungan hidup/pertanian, (4) rumah, (5) pendidikan, (6) upacara perkawinan dan kelahiran, (7) makanan, (8) siklus kehidupan manusia dan watak, (9) kesehatan, (10) bencana alam.

Koentjaraningrat (Abidin \& Beni, 2014: 168) berpandangan bahwa budaya lokal terkait dengan suku bangsa, yaitu gologan manusia yang terkait oleh kesadaran dan identitas "kesatuan kebudayaan". Budaya lokal atau kearifan lokal itu lebih khusus berdasarkan golongan etnis, profesi, wilayah, atau daerah. Contohnya, budaya Dieng. Kearifan lokal dengan demikian terkait semua mengenai budaya lokal baik suku, adat istiadat, kesenian, maupun pandangan hidup masyarakat setempat dalam berbagai aktivitas masyarakat lokal dalam memenuhi kebutuhan seluruh aspek kehidupan masyarakat.

Masa depan peradaban Indonesia yang modern harus bertumpu pada peradaban yang berbudi luhur dan berkarakter, yang diharapkan akan mampu bersaing dengan peradaban dunia lain. Warisan budaya lokal adalah modal besar dan potensi untuk membentuk karakter bangsa yang tangguh. Kearifan lokal ini dapat berupa tradisi, pepatah, semboyan hidup, ataupun makna filosofis dari kesenian dan adat istiadat masyarakat setempat.

Menurut Suyatno (2011:83), walaupun ada upaya pewarisan kearifan lokal dari generasi ke generasi, tidak ada jaminan bahwa kearifan lokal akan tetap kokoh menghadapi gempuran globalisasi yang menawarkan gaya hidup yang semakin pragmatis dan konsumtif. Faktanya kearifan lokal yang nyaris tidak terimplementasikan dalam praktik hidup yang makin pragmatis. Ini artinya bahwa walaupun bangsa Indonesia mempunyai kearifan lokal atau budaya lokal yang mengandung nilainilai luhur yang sangat baik akan sangat percuma jika bangsa Indonesia tidak mengimplementasikan nilai-nilai luhur tersebut dalam kehidupan seharihari. Hal ini karena kearifan lokal tidak melulu membicarakan budaya, tetapi juga membicarakan ekonomi, sosial, dan politik. Oleh karena itu, bangsa Indonesia harus mampu memajukan perekonomian, masalah sosial, dan politik melalui kearifan lokal. Pertanyaan yang diajukan adalah bagaimana bangsa Indonesia menyelesaikan masalah ekonominya dan mampu bertahan hidup dengan kearifan lokal yang dimilikinya.

Pendidikan karakter berbasis kearifan lokal harus sesuai dengan nilai-nilai yang terkandung dalam agama, Pancasila, kebudayaan, dan tujuan pendidikan. Masyarakat Indonesia merupakan masyarakat yang beragama. Ini artinya bahwa 
dalam kehidupan masyarakat selalu didasari ajaran agama yang dianutnya dan selanjutnya adalah berdasarkan nilai-nilai Pancasila. Dalam kehidupan bermasyarakat, berbangsa, dan bernegara haruslah didasarkan nilai-nilai Pancasila. Karakter itu sendiri tidak pernah lepas dari nilai budaya. Nilai budaya mencerminkan karakter masyarakat tersebut. Tujuan pendidikan tercantum dalam UndangUndang Republik Indonesia Nomor 20 Tahun 2003 yang merumuskan tujuan pendidikan nasional yaitu mengembangkan dan membentuk watak serta peradaban bangsa yang bermartabat dalam rangka mencerdaskan kehidupan bangsa.

Hal ini dapat disimpulkan bahwa kearifan lokal tidak akan lepas dari kehidupan manusia sekaligus menjadi filter pada zaman globalisasi dalam kehidupan manusia. Nilai-nilai kearifan lokal sangat berperan dalam kemajuan suatu bangsa.

\section{Pendidikan Kewarganegaraan sebagai Sarana Pembangunan Karakter Bangsa}

Secara umum di setiap negara, pengembangan pendidikan kewarganegaraan bertujuan untuk menjadikan warga negara yang baik (to be good citizen). Warga negara yang baik artinya adalah warga negara yang memiliki kecerdasan, yaitu kecerdasan intelektual, emosional, sosial, dan spiritual. Setiap warga negara dituntut untuk dapat hidup berguna dan bermakna bagi bangsa dan negaranya. Pendidikan karakter dalam materi PKn merupakan salah satu misi yang harus diwujudkan. Misi lain adalah pendidikan demokrasi, pendidikan hukum, pendidikan HAM, pendidikan antikorupsi. PKn dan Agama merupakan mata pelajaran yang mempunyai tujuan utama, yaitu membangun karakter bangsa. Sesuai dengan pendapat Fusnika (2014:51), bahwa PKn merupakan salah satu instrumen fundamental dalam bingkai pendidikan nasional sebagai media bagi pembentukan karakter bangsa di tengah heterogenitas atau pluralisme yang menjadi karakteristik utama bangsa Indonesia.

Seperti halnya kegiatan $D C F$, kajian makna nilai-nilai $D C F$ adalah sebagai upaya pembangunan karakter bangsa. Kegiatan lain dalam pendidikan adalah dengan cara mencantumkan nilai kearifan lokal $D C F$ dalam pembelajaran, khususnya dalam mata pelajaran PKn. Oleh karena itu, PKn dipelajari sejak tingkat Sekolah dasar sampai perguruan tinggi dengan tujuan dan mempunyai tanggung jawab sebagai wahana pembentukan dan pembangunan karakter bangsa.

Keterkaitan antara pendidikan karakter dan pendidikan kewarganegaraan salah satunya adalah pendidikan karakter merupakan bagian dari pendidikan kewarganegaraan karena di dalam pendidikan kewarganegaraan diajarkan nilai, moral, dan karakter atau nilai kebajikan untuk membentuk warga negara yang berkarakter. Dapat disimpulkan banwa pendidikan kewarganegaraan merupakan salah satu konsep pendidikan yang berfungsi untuk mengembangkan atau membentuk karakter siswa untuk menjadi warga negara yang baik. Diharapkan dalam pendidikan kewarganegaraan dapat menanamkan kebiasaan yang baik sehingga peserta didik mampu bertindak berdasarkan nilai yang sudah menjadi kepribadiannya, tidak hanya mengajarkan pengetahuan saja tetapi lebih pada pembentukan sikap yang baik. Keterkaitan antara $D C F$ dengan pendidikan karakter adalah $D C F$ sebagai wahana untuk menanamkan nilai yang bertujuan untuk membentuk karakter bangsa.

\section{Persepsi Masyarakat Dieng terhadap Transformasi Nilai Budaya Tradisi Dieng Culture Festival}

Penelitian ini, dilihat dari sudut pandang pendidikan kewarganegaraan mencoba mengaitkannya dengan pembangunan karakter bangsa melalui tradisi $D C F$. Penelitian sebelumnya membahas dari sudut pandang ekonomi, pariwisata, psikologis, maka kali ini penulis mencoba dari sudut pandang pendidikan kewarganegaraan. Penulis mencoba memaparkan makna simbol-simbol yang ada dalam tradisi $D C F$. Bermula dari sejarah tradisi tersebut hingga akhirnya menemukan nilai-nilai karakter atau nilai kebajikan yang dapat diadopsi di dalam kehidupan berbangsa dan bernegara. Nilai-nilai kebajikan ini dirumuskan dari makna simbol-simbol dan sejarah tradisi pemotongan rambut gimbal, tari rampak yakso, dan wayang. Nilai-nilai tersebut kemudian dapat dijadikan 
sebagai pedoman hidup masyarakat sehingga dapat membangun karakter bangsa.

Budaya Dieng tidak diartikan hanya sebagai tarian atau yang berkaitan dengan kesenian, tetapi budaya Dieng meliputi kepercayaan terhadap tradisi ritual cukur rambut gimbal, pengetahuan tentang asal usul tradisi, norma, dan adat istiadat yang dipelihara oleh masyarakat serta kebiasaan hidup sebagai petani dalam mencapai kebutuhan keluarganya. Hal ini sependapat bahwa dalam kebudayaan terkandung ilmu pengetahuan, kepercayaan, kesenian, adat istiadat, dan kemampuan yang lain serta kebiasaan yang diadaptasi oleh manusia sebagai anggota masyarakat (Sulasman \& Gumilar, 2013: 57-59; Yunus, 2014: 1-4).

Unsur-unsur kebudayaan dibagi menjadi tujuh: (a) bahasa, (b) sistem pengetahuan, (c) organisasi sosial, (d) sistem peralatan hidup dan teknologi, (e) sistem mata pencaharian hidup, (f) sistem religi, (g) kesenian (Koentjaraningrat, 1990: 206-208; Sulasman \& Gumilar, 2013: 39-46).

Berdasarkan temuan penelitian unsur kebudayaan yang pertama adalah bahasa. Masyarakat Dieng Kulon menggunakan bahasa Jawa Banyumas dalam kehidupan sehari-hari. Unsur kebudayaan yang kedua adalah sistem pengetahuan. Di Dieng Kulon terdapat sekolah TK, SD, dan madrasah pengajian yang biasanya digunakan oleh anak-anak Dieng Kulon. Unsur kebudayaan yang ketiga adalah organisasi sosial. Organisasi sosial masyarakat di Dieng Kulon seperti PKK, Pokdarwis, dan Karang Taruna. Unsur kebudayaan yang keempat adalah sistem peralatan hidup dan teknologi, peralatan dalam pertanian khususnya sudah menggunakan alat penyemprot pupuk. Masyarakat Dieng Kulon sudah banyak yang mengangkut hasil pertanian dengan menggunakan motor dan mobil pribadi. Masyarakat Dieng Kulon dalam teknologi komunikasi sudah banyak yang memiliki handphone dan telepon rumah. Unsur kebudayaan yang kelima adalah sistem mata pencaharian hidup. Mata pencaharian masyarakat Dieng Kulon adalah sebagai petani, dengan komoditas utama kentang dan carica. Masyarakat Dieng Kulon selain menanam kentang dan carica, juga menanam sayuran kol, kubis, terong belanda, cabai. Unsur kebudayaan keenam adalah sistem religi. Masyarakat Dieng Kulon sebagian besar menganut agama Islam. Masyarakat Dataran Tinggi Dieng memiliki kepercayaan dan upacara ritual cukur rambut gimbal. Masyarakat Dataran Tinggi Dieng memercayai bahwa tujuan dari ritual tersebut adalah untuk menghilangkan balak. Untuk menghilangkan balak tersebut masyarakat Dataran Tinggi Dieng memohon keselamatan kepada Tuhan Yang Maha Esa. Oleh karena itu, dalam kegiatan sehari-hari masyarakat Dieng Kulon berlandaskan syariat Islam. Unsur kebudayaan yang ketujuh adalah kesenian. Kesenian yang tumbuh dalam masyarakat Dieng adalah tari rampak yakso, tari kuda lumping, tari lengger, dan wayang kulit.

Fortes (Tilaar, 1999:54) mengemukakan tiga variabel utama dalam transformasi budaya, (1) unsur-unsur yang ditransformasikan, (2) proses transformasi, dan (3) cara transformasi. Unsurunsur yang dapat ditransformasikan berupa nilai budaya, adat-istiadat masyarakat, konsep kehidupan masyarakat, sikap dalam pergaulan masyarakat, dan cara hidup dalam masyarakat.

Berdasarkan temuan penelitian unsur-unsur transformasi adalah berupa nilai budaya dan adat istiadat. Nilai budaya yang terkandung dalam $D C F$ yang dapat ditranformasikan dalam kehidupan bermasyarakat adalah (1) nilai religius: kejujuran, keadilan, kebenaran, dan kesholehan yang ditampilkan oleh pemangku adat Dieng dalam memimpin upacara ritual. Dalam upacara ritual dibacakan doa-doa yang terdapat dalam Alquran. Kegiatan ritual ini bertujuan untuk meminta keselamatan kepada Allah SWT untuk anak yang dititipi sakit dengan cara yang berbeda agar sehat dan mendapat perlindungan dari Allah. Berbagai peninggalan masa lampau umat Hindu terdapat di Dieng, antara lain candi, arca, batu tulis, dan situs purbakala lain. Masyarakat Dieng walaupun banyak memiliki peninggalan umat Hindu, masyarakat Dieng hampir semua telah memeluk Islam. Masyarakat dengan demikian tetap melestarikan dan menjaga tempat ibadah umat Hindu tersebut. Masyarakat sangat menghormati dan menghargai apa pun peninggalan para leluhur. Ritual cukur rambut gimbal pun biasanya dilaksanakan di kompleks Candi Arjuna. 
(2) nilai estetika (keindahan): nilai estetika ini ditampilkan dalam bentuk karya seni baik itu berupa suara, musik, maupun tarian. Dalam ritual cukur rambut dari awal sampai ritual selesai, diiringi oleh tembang macapat dan gamelan. Pada saat kirab budaya akan diiringi oleh berbagai tarian seperti tari rampak yakso dan kuda lumping.

(3) nilai kemanusiaan: nilai kemanusiaan ini ditampilkan dalam prosesi ngalab berkah, yang mengajarkan untuk berbagi dan memberikan sebagian rezeki kepada orang lain. Prosesi pelarungan mengajarkan untuk berbagi rezeki kepada makhluk Allah yang lain seperti hewan dan tumbuhan.

(4) nilai kebersamaan: nilai kebersamaan ditampilkan dalam keterlibatan masyarakat dalam ritual cukur rambut gimbal yang dibungkus dengan $D C F$. Gotong royong dilaksanakan untuk mempersiapkan ritual cukur rambut massal. Cukur rambut massal ini adalah untuk meringankan beban biaya ritual kepada para orang tua dan sekaligus melestarikan dan memperkenalkan budaya lokal Dieng kepada para wisatawan.

(5) nilai demokratis: nilai demokratis terlihat dalam persiapan menjelang ritual massal cukur rambut gimbal. Berbagai aspirasi ditampung dan dimusyawarahkan agar mencapai keputusan secara demokratis dan bertanggung jawab.

(6) nilai kemakmuran: nilai kemakmuran ini dapat dilihat dari bertambahnya penghasilan masyarakat yang dikarenakan oleh DCF. Bertambahnya penghasilan tersebut dari penjualan tiket, penjualan makanan, oleh-oleh, pernakpernik, dan jasa homestay.

Dalam $D C F$ terdapat seni pertunjukan wayang kulit. Wayang merupakan salah satu warisan masyarakat Jawa yang hingga kini masih popular. Wayang telah diakui Unesco sebagai Masterpiece of Oral and Intangible Heritage of Humanity (karyakarya agung lisan dan tak benda warisan manusia). Wayang ini memiliki nilai tinggi bagi peradaban manusia dan mengandung penuh ajaran moral yang tinggi sehingga wayang disebut sebagai karya agung. Karya agung dan penuh ajaran moral tinggi ini dapat mentransformasikan nilai-nilai yang ada di dalam wayang untuk upaya pembangunan karakter bangsa.
Menurut Wibisono (Nurgiantoro, 2011:20), untuk menjadi karya agung dunia terdapat enam persyaratan yang harus terpenuhi, yaitu: (1) nilai luar biasa sebagai karya agung ciptaan manusia; (2) berakar pada tradisi budaya atau sejarah budaya masyarakat yang bersangkutan; (3) berperan sebagai sarana pernyataan jati diri bangsa atau suku bangsa yang bersangkutan yang berfungsi sebagai sumber inspirasi pertukaran budaya, sebagai sarana membuat rakyat semakin dekat satu dengan yang lain, dan peran sosialnya masa kini dalam masyarakat yang bersangkutan; (4) kegunaan dalam penerapan keterampilan dan sifat teknik yang diperlihatkan; (5) perannya sebagai tradisi budaya yang hidup; (6) risiko budaya yang bersangkutan bisa punah karena kekurangan sarana untuk melestarikan dan melindunginya.

Berdasarkan temuan penelitian, wayang merupakan karya agung yang mempunyai moralitas tinggi ciptaan manusia, wayang berasal dari sejarah masyarakat Jawa. Pagelaran wayang adalah wahana untuk membuat rakyat sebagai penonton semakin dekat satu sama lain, dan wayang berperan sebagai tradisi yang hidup di dalam masyarakat. Wayang merupakan salah satu budaya yang bersifat lisan dan tak benda yang penting untuk dilestarikan.

Nilai karakter yang terkandung dalam karakter bangsa adalah nilai-nilai yang berlaku, diyakini, dan disepakati untuk dilaksanakan oleh setiap masyarakat di suatu negara. Nilai karakter tersebut bisa didapatkan dari wayang. Nilai-nilai karakter merupakan nilai-nilai luhur yang kemudian dijadikan pedoman dalam hidup. Menurut Nurgiyantoro (2011: 29), cerita wayang dan karakter para tokohnya banyak yang dijadikan panutan, prinsip hidup, sumber pencarian nilainilai, atau paling tidak memengaruhi sikap hidup masyarakat penggemar cerita itu. Berdasarkan temuan penelitian, wayang bukan saja merupakan suatu bentuk kesenian yang digemari, namun telah menjadi bagian hidup yang dibutuhkan masyarakat. Cerita wayang menampilkan dua kelompok yang bertentangan: kelompok baik dan kelompok jahat. Kelompok dengan karakter baik inilah yang dapat dijadikan teladan, inspirasi, dan pembangun karakter bangsa. Tidak sedikit juga para orang tua kadang memberi nama sang anak 
menggunakan nama tokoh baik dalam wayang, seperti Yudhistira, Bima, Arjuna, Sadewa, dan Kresna. Tokoh baik wayang sangat membekas di hati masyarakat Indonesia, dalam hal ini masyarakat Jawa khususnya. Seni wayang mengandung banyak nilai dari falsafah hidup spiritual, etika, musik, hingga keindahan atau estetika. Nilai yang terkandung dalam wayang antara lain nilai religius, nilai gotong royong, nilai kerukunan, nilai kedamaian, nilai kepedulian, nilai ketentraman.

Hal ini sejalan dengan pendapat Udasmoro (1999:39) yang menyatakan bahwa wayang berisi pesan-pesan yang disampaikan oleh dan untuk masyarakat baik secara sadar (conscious) sebagai sarana pendidikan maupun secara tidak sadar (unconscious) sebagai sarana filosofis. Oleh karena itu dapat disimpulkan bahwa pembangunan karakter bangsa tidak lepas dari tradisi nilai luhur yang dimiliki oleh bangsa Indonesia selama tradisi nilai luhur tersebut mampu mengikuti dan masih relevan dengan zaman yang semakin modern. Dalam hal ini harus dipercayai bahwa eksistensi bangsa Indonesia dewasa ini tidak lepas dari nilainilai luhur tradisional yang memiliki sejarah yang amat panjang dalam mengawal pertumbuhan dan kemajuan bangsa ini yang salah satunya adalah wayang. Pertunjukan wayang kulit mengandung makna filosofi mendalam dan berisi berbagai ajaran dan nilai-nilai estetika dan etika. Memahami wayang berarti dapat mengenali kehidupan sendiri. Lakon-lakon yang ditampilkan seolaholah menggambarkan kehidupan manusia sendiri (Nurgiyantoro, 2011:28-29; Lestari, 2006:1-2).

Masyarakat Dieng memercayai bahwa sang anak berambut gimbal adalah titisan Mbah Kolodete sehingga harus diruwat. Ada yang menyebutkan bahwa berambut gimbal itu sebenarnya merupakan suatu penyakit yang disebabkan oleh dinginnya suhu Dieng, kurangnya menjaga kebersihan, dan asupan makanan yang salah. Namun anehnya, jika hal tersebut merupakan suatu penyakit seharusnya jika diperiksakan ke dokter dan meminum obat maka akan sembuh. Akan tetapi, pada kenyataannya tidak sembuh. Justru rambut gimbal tersebut tidak akan tumbuh kembali ketika anak tersebut telah melakukan ruwatan pada waktu yang tepat. Waktu yang tepat adalah waktu ketika anak tersebut meminta dipotong dan sudah mengajukan permintaannya. Bagi masyarakat Dieng, upacara ruwatan ini memiliki makna yang sakral. Masyarakat Dieng yakin jika sang anak sudah diruwat dan dipotong rambutnya, sang anak telah terbebas dari sukerta (malapetaka) yang dititipkan oleh Mbah Kolodete. Ketenangan hati dapat dirasakan para orang tua yang sudah meruwat dan memotong rambut sang anak yang gimbal.

Kirab budaya ini dimulai dari rumah pemangku adat yang berada di Gang Pringgondani. Dalam kirab tersebut diiringi oleh rombongan tetua adat, tokoh masyarakat, anak bajang (berambut gimbal) bersama dengan para orang tuanya, dan berbagai kesenian. Di barisan pertama adalah sesepuh adat dan pemangku adat. Para rombongan pertama tersebut memakai pakaian tradisional Jawa lengkap dengan pakaian beskap hitam, kain batik, pelengkap blangkon, dan pusaka yang dipakai di belakangnya. Baris yang kedua adalah pembawa sesaji dan barang-barang permintaan anak rambut gimbal. Barisan ketiga adalah sang anak bajang dan para orang tuanya, dan barisan yang terakhir adalah rombongan kesenian. Setelah berkeliling

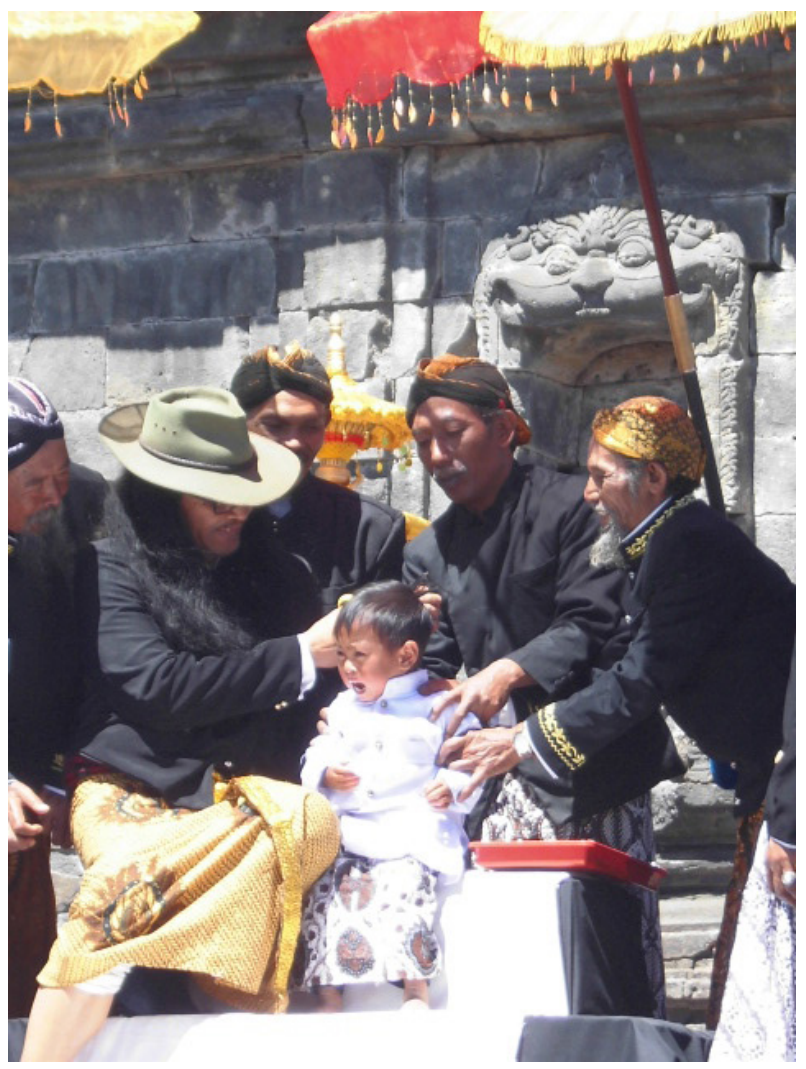

Gambar 1. Prosesi pemotongan rambut gimbal (Foto: Yuni 2015) 
Dieng, rombongan tersebut berhenti di Sendang Sedayu untuk melakukan ritual jamasan. Ritual jamasan ini adalah ritual siraman sang anak bajang. Ritual ini diawali dengan pembacaan doa oleh tetua adat di depan pintu Sendang Sedayu. Setelah pembacaan doa, satu per satu sang anak dibasahi rambutnya. Sang anak kemudian dikawal menuju tempat pencukuran di kompleks Candi Arjuna. Sesampainya di Candi Arjuna para rombongan disambut oleh wisatawan dan penonton serta musik gamelan. Sebelum memotong rambut gimbal, terlebih dahulu sang pemangku adat membacakan doa. Setelah membacakan doa, satu per satu sang anak dipotong rambutnya dan rambut tersebut dibungkus dengan kain dan dimasukkan ke dalam kendi kecil untuk dilarungkan ke Telaga Warna. Setelah dicukur, panitia menyerahkan benda yang diminta oleh sang anak gimbal.

Selesai prosesi pencukuran, ada prosesi ngalab berkah. Ngalab berkah ini adalah memperebutkan sesaji yang terdiri dari tumpeng robyong, ayam ingkung, jajanan pasar, dan buah-buahan. Masyarakat Dieng memercayai bahwa orang yang mendapatkannya akan mendapat berkah. Setelah ngalah berkah selesai, maka saatnya pelarungan rambut gimbal yang sudah dipotong dan sebagian sesaji. Pelarungan ini dilakukan di Telaga Warna yang nantinya akan mengalir ke Sungai Serayu dan akan bermuara di Laut Selatan. Inilah adat istiadat yang masih dilestarikan oleh masyarakat Dieng. Dalam peristiwa ini terdapat banyak wisatawan yang datang hanya untuk melihat adat istiadat yang unik ini sehingga dapat menambah penghasilan masyarakat Dieng.

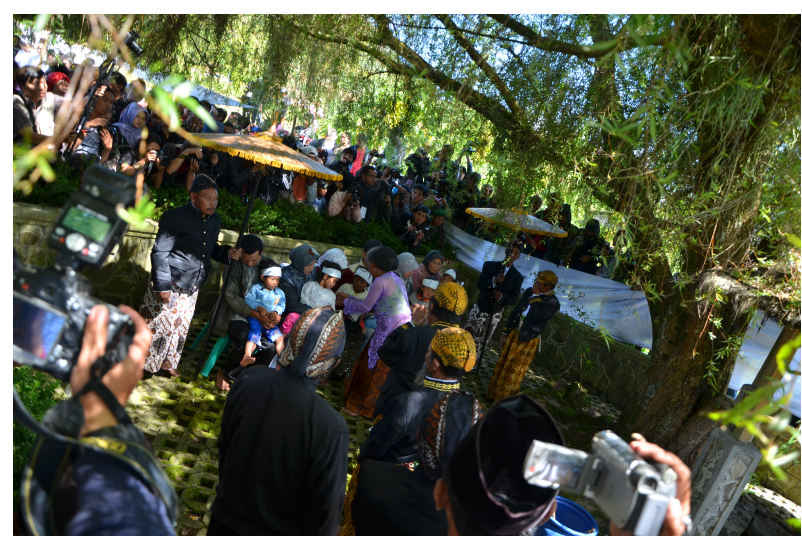

Gambar 2. Prosesi perarakan anak bajang (Foto: Yuni 2015)
Proses transformasi ini ada tiga, yaitu imitasi, identifikasi, dan sosialisasi. Berdasarkan temuan penelitian, proses transformasi melalui proses imitasi adalah masyarakat mengaplikasikan atau meniru tingkah laku dari lingkungan sekitar. Hal yang diimitasi ini adalah unsur-unsur yang berupa nilai budaya, adat istiadat, dan pergaulan di dalam masyarakat. Adat istiadat ritual cukur rambut gimbal mengandung nilai religius sehingga di dalam kehidupan yang sebenarnya masyarakat bertindak religius. Bertindak religius seperti halnya taat dan patuh terhadap agama yang dianutnya. Dalam hal ini menjadikan agama atau kepercayaannya merupakan pedoman hidup atau pegangan hidup. Unsur-unsur tersebut harus diidentifikasikan sesuai dengan tingkat kemampuan manusia itu sendiri. Nilai dari unsur-unsur tersebut disosialisasikan dalam lingkungan keluarga, masyarakat, dan sekolah agar semua warga dalam keluarga, warga dalam masyarakat, dan warga dalam sekolah memahami dan dapat menjalankan sesuai dengan apa yang dicita-citakan tanpa mengubah makna dari unsur-unsur tersebut.

Cara untuk mentransformasikan budaya yang paling utama adalah dengan cara peran serta. Peran serta ini merupakan cara transformasi budaya melalui partisipasi atau peran serta masyarakat dalam kegiatan sehari-hari. Masyarakat dalam hal ini terjun langsung dalam kegiatan tersebut seperti kegiatan cukur rambut gimbal dan ritual lain. Bimbingan dalam hal ini dapat berupa hukuman dan teguran dalam lingkungan masyarakat. Hal ini mungkin lebih tepatnya sebagai pengingat ataupun sebagai norma-norma yang ada dalam masyarakat. Dalam masyarakat desa yang belum ada pengaruh globalisasi, terdapat norma-norma yang kental dan masih dijaga oleh masyarakat. Kondisi ini juga terjadi di Dieng, di mana masyarakatnya masih menaati betul norma yang sudah ada sejak dulu. Masyarakat Dieng secara turun-temurun mempertahankan dan melestarikannya.

Berdasarkan analisis tersebut dapat disimpulkan bahwa persepsi masyarakat Dieng mengenai tradisi cukur rambut gimbal memiliki makna yang sakral dalam kehidupan masyarakat. Persepsi masyarakat Dieng mengenai tradisi $D C F$ adalah mengajarkan sebagai manusia untuk 
menjaga keharmonisan hubungan manusia dengan Tuhan, hubungan manusia dengan sesama manusia, dan hubungan manusia dengan alam sekitar. Secara turun-temurun masyarakat Dieng mentransformasikan adat istiadat tersebut tanpa mengubah makna sebenarnya dari cukur rambut gimbal. Tradisi $D C F$ memiliki beberapa nilai budaya yang dapat ditransformasikan dan diaplikasikan dalam kehidupan sehari-hari. Nilainilai tersebut adalah nilai religius, nilai kemanusian, nilai estetika, nilai kebersamaan, nilai demokratis, nilai kemakmuran, nilai gotong royong, nilai kerukunan, nilai kedamaian, nilai kepedulian, dan nilai ketenteraman. Dapat disimpulkan bahwa pembangunan karakter bangsa tidak lepas dari nilai luhur yang dimiliki oleh bangsa Indonesia selama tradisi nilai luhur tersebut mampu mengikuti dan masih relevan dengan zaman yang semakin modern.

\section{Relevansi Nilai Budaya Tradisi Ritual Pemotongan Rambut Gimbal, Tari Rampak Yakso, Kuda Lumping, dan Wayang dalam Tradisi $D C F$}

Menurut Kluchkohn (Yunus, 2014: 105), setiap sistem nilai budaya dalam tiap kebudayaan mengandung lima masalah dasar dalam kehidupan manusia, yakni hakikat hidup, hakikat kerja, hakikat waktu, hakikat hubungan manusia dengan sesamanya, dan hakikat hubungan manusia dengan alam sekitarnya. Berdasarkan temuan penelitian, DCF mengandung kelima masalah dasar dalam kehidupan manusia tersebut. Pertama, hakikat makna. Dalam kegiatan $D C F$, masyarakat
Dieng dapat memaknai hidup di dunia. DCF mengajarkan untuk selalu bergotong royong dalam hal apa pun untuk kepentingan bersama. Dalam upacara ritual cukur rambut gimbal, dalam hal ini mengajarkan untuk saling ingat kepada Tuhan Yang Maha Esa karena selalu diberi kesempatan untuk hidup serta memiliki kesehatan, kebahagiaan hidup, dan apa pun itu dilakukan hanya karena Tuhan Sang Mahakuasa. Upacara ritual ini dengan demikian memberikan anggapan bahwa masyarakat Dieng mendapatkan kekuatan spiritual untuk menyelamatkan dan menghindarkan dari segala macam bencana. Kegiatan upacara ini tidak lepas dari ajaran agama yang mereka anut.

Kedua, hakikat kerja atau hakikat dari karya manusia. Kegiatan DCF mengajarkan bahwa meningkatkan nilai kemakmuran dengan mengembangkan budaya lokal adalah hak asasi manusia. Para generasi muda melestarikan budaya dan tradisi masyarakat Dieng sekaligus menambah nilai kemakmuran dalam kegiatan $D C F$. Warga masyarakat yang sehari-hari berprofesi petani dapat berpartisipasi dalam kegiatan kesenian tari dan ritual cukur rambut gimbal serta dapat mengembangkan usaha produksi oleh-oleh dan pernak-pernik miniatur wayang ataupun candi.

Ketiga, hakikat waktu. Berjalan dan berputarnya waktu tidak dapat dihindari. Waktu merupakan hal yang tidak dapat diputar kembali sehingga jika manusia tidak berhati-hati dalam mempergunakan waktu, manusia akan rugi. Tradisi, begitu juga dari waktu ke waktu lambat laun akan terkikis oleh zaman. Oleh karena itu, manusia harus melestarikannya. Masyarakat Dieng sadar bahwa nilai-nilai tradisi semakin lama akan
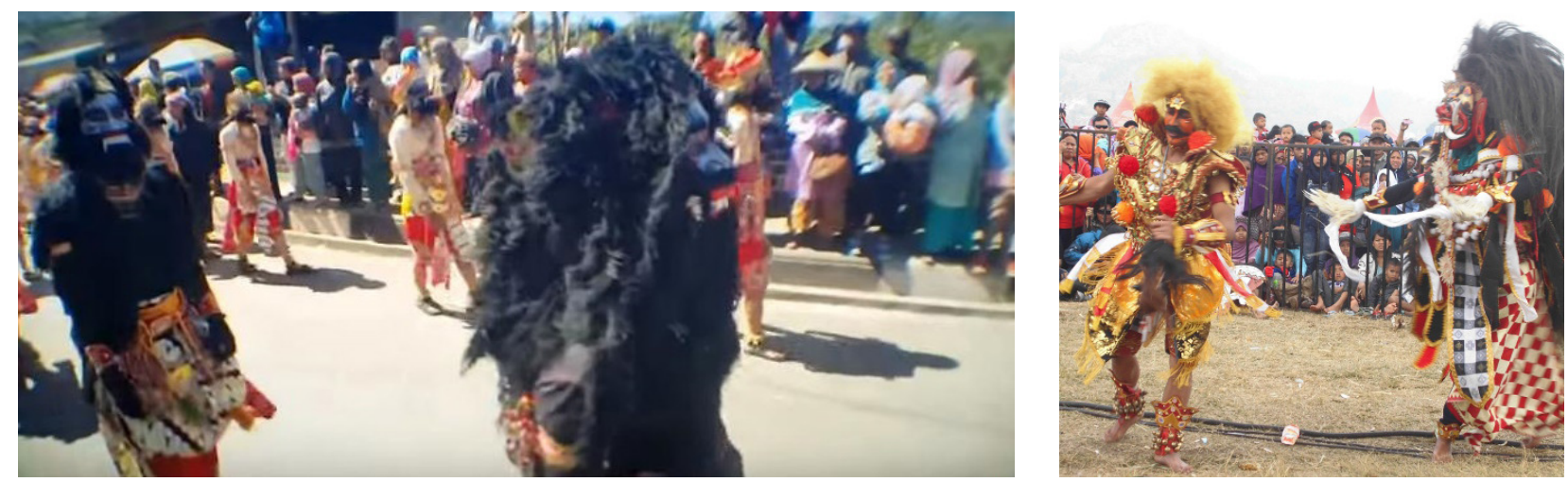

Gambar 3. Tari kolosal Rampak Yakso diperagakan oleh pemuda dan masyarakat yang sebagian besar berprofesi sebagai petani (Foto: Yuni 2015) 
semakin banyak yang ditinggalkan oleh masyarakat. Oleh karena itu, masyarakat Dieng melestarikan nilai tradisi tersebut melalui kegiatan $D C F$ karena kegiatan tersebut mampu menarik banyak kalangan untuk melestarikannya.

Keempat, hakikat hubungan manusia dengan alam sekitarnya. Melalui $D C F$, masyarakat Dieng dapat menjaga keseimbangan hubungan manusia dengan alam. Dalam tradisi upacara ritual cukur rambut gimbal yang dilaksanakan dalam $D C F$ mengajarkan bagaimana menjaga keseimbangan dengan alam. Hal ini dapat dilihat saat napak tilas ke mata air lalu ke Telaga Warna. Saat itulah warga masyarakat asli menjaga alam. Napak tilas tersebut memberi gambaran bahwa sebagai manusia wajib merawat dan bersyukur atas limpahan alam yang Tuhan berikan. Dalam $D C F$ pun terdapat kegiatan penanaman pohon kembali dan pemungutan sampah. Kegiatan DCF dengan demikian bukan hanya kegiatan yang hanya melestarikan budaya, tetapi kegiatan untuk melestarikan alam dan lingkungan. Oleh karena itu, $D C F$ dapat dikatakan sebagai kegiatan dalam masyarakat yang berkaitan dengan alam dan lingkungan. Hal ini sependapat dengan (Fahrianoor, 2013: 38), yang menyatakan bahwa local wisdom is related to activities of the community, especially in relation with interaction towards the nature. Kearifan lokal yang berkaitan dengan kegiatan masyarakat dengan demikian menurut Fahrianoor dkk. berkaitan dengan interaksi masyarakat terhadap alam.

Kelima, hakikat hubungan manusia dengan manusia lain. Secara umum, manusia membutuhkan manusia lain untuk hidup. Hal ini tercermin dalam

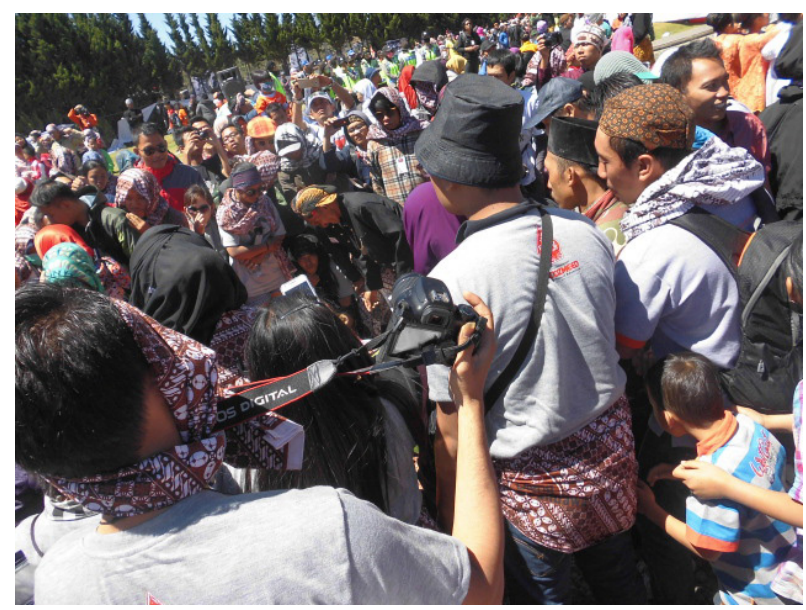

Gambar 4. Persiapan ngalab berkah (Foto: Yuni 2015) kegiatan upacara ritual cukur rambut gimbal dalam $D C F$, terlihat masyarakat saling bergotong royong dalam melaksanakan kegiatan ini. Masyarakat dan panitia mengajak peserta untuk bergotong royong dalam kebersamaan menjaga lingkungan.

Kearifan lokal identik dengan perilaku manusia yang berhubungan dengan: (1) Tuhan, (2) tanda-tanda alam, (3) lingkungan hidup/pertanian, (4) membangun rumah, (5) pendidikan, (6) upacara perkawinan dan kelahiran, (7) makanan, (8) siklus kehidupan manusia dan watak, (9) kesehatan, (10) bencana alam sehingga kearifan lokal merupakan bagian dari tradisi budaya yang dinamis dan dapat diciptakan dari kemampuan masyarakat untuk menerima pengaruh luar melalui proses kreatif yang melahirkan ciptaan baru yang kreatif (Wagiran, 2012: 4-7; Dahliani, 2015: 163-165).

Berdasarkan temuan penelitian, kearifan lokal masyarakat dataran tinggi Dieng dapat dilihat berdasarkan kearifan lokal yang berhubungan dengan Tuhan Yang Maha Esa, kehidupan seharihari, selanjutnya dengan berbagai upacara ritual yang mereka miliki, kemudian kearifan lokal dalam menjaga keharmonisan dan kearifan lokal yang berkaitan dengan seni. Dalam masyarakat Jawa tertanam konsep tentang menjaga hubungan yang harmonis antara manusia dengan Tuhan, manusia dengan manusia, dan manusia dengan lingkungan. Konsep tersebut bertujuan untuk tercapainya hidup yang selaras, serasi, dan seimbang. Masyarakat Dieng sangat menjaga hubungan baik dengan Tuhan, dan hal ini dapat dilihat dari cara masyarakat Dieng menjalankan kewajiban sebagai umat Tuhan yang baik. Kehidupan sehari-hari masyarakat Dieng adalah sebagai petani yang sederhana dan selalu berusaha untuk meningkatkan baik itu ekonomi maupun SDM untuk memajukan Desa Dieng. Masyarakat Dieng mempunyai berbagai upacara ritual, salah satunya adalah ritual cukur rambut gimbal. Ritual cukur rambut gimbal merupakan ritual spiritual yang menciptakan ketenangan hati masyarakat, yakni ucapan syukur dan meminta keselamatan kepada Tuhan Sang Maha Pencipta. Upacara ritual ini bertujuan untuk menjaga ke-seimbangan antara manusia dengan Tuhan, manusia dengan manusia, dan manusia dengan alam. 
Kearifan lokal masyarakat Dieng dapat dilihat dari keharmonisan dalam berbagai kegiatan yang ada di masyarakat. Setiap hari Jumat selalu diadakan bersih desa dengan cara gotongroyong. Gotong royong merupakan budaya bangsa yang telah lama. Wujud gotong royong ini seperti yang telah masyarakat Dieng lakukan antara lain membersihkan lingkungan, pesta pernikahan, upacara adat, dan saat terjadi bencana alam. Diharapkan gotong royong menjadi landasan semangat untuk membangun bangsa. Dengan gotong royong dapat bersatu maju membangun bangsa. Intisari dari Pancasila adalah gotong royong dengan tujuan untuk mencapai keadilan sosial bagi seluruh rakyat Indonesia.

Sesuai dengan pernyataan Soekarno dalam pidato 1 Juni 1945: "Gotong royong adalah pembantingan-tulang bersama, pemerasankeringat bersama, pemerasan-keringat bersama, perjoangan bantu-binantu bersama. Amal semua buat kepentingan semua, keringat semua buat kebahagiaan semua. Ho-lopis-kuntul-baris buat kepentingan bersama! Itulah gotong royong!" Dalam kegiatan ini tercipta keharmonisan dalam masyarakat dengan tujuan bersama yaitu untuk menjaga lingkungan agar tetap bersih dan sehat. Kearifan masyarakat Dieng dapat dilihat melalui seni, baik itu seni tari maupun seni wayang. Seni tari antara lain berupa seni tari rampak yakso dan kuda lumping. Cerita dari seni tari dan seni wayang ini dapat menjadi teladan bagi masyarakat Dieng.

Hal ini sejalan dengan pendapat Sukirno (2009: 24), yang menyatakan bahwa bagi manusia Jawa, wayang merupakan pedoman hidup yaitu bagaimana masyarakat Jawa bertingkah laku dengan sesama dan bagaimana menyadari hakikatnya sebagai manusia serta bagaimana dapat berhubungan dengan sang penciptanya. Diperkuat dengan hasil penelitian Sukatno (2003: 15), yang menyatakan bahwa aspek-aspek yang terkandung di dalam pertunjukan wayang antara lain aspek pendidikan, aspek harapan, aspek religius, dan aspek filosofi. Hal ini dapat dilihat baik dari simbol, lambang, dan lakon-lakon wayang yang dipergunakan dalam pertunjukan.

Dikatakan pula oleh Wagiran (2012:6), lingkup kearifan lokal dapat dibagi menjadi delapan, yaitu (1) norma-norma lokal yang dikembangkan, seperti 'laku Jawa', pantangan dan kewajiban; (2) ritual dan tradisi masyarakat serta makna di sebaliknya; (3) legenda dan mitos yang biasanya mengandung pesan-pesan tertentu yang hanya dikenali oleh komunitas lokal; (4) pengetahuan yang terhimpun pada pemimpin adat; (5) kitab suci yang diyakini kebenarannya oleh masyarakat; (6) cara komunitas lokal dalam memenuhi kehidupan sehari-hari; (7) alat/bahan untuk memenuhi kebutuhan tertentu; dan (8) kondisi sumber daya alam yang dimanfaatkan dalam penghidupan masyarakat sehari-hari.

Berdasarkan temuan penelitian, masyarakat Jawa mempunyai berbagai norma Jawa atau konsep Jawa yang dipakai dalam menjalankan kehidupannya. Di sekolah diajarkan konsep akhlak kang mulya, temuning jati diri iman lan taqwa. Arti dari konsep tersebut adalah karakter yang mulia ditemukan dalam diri yang iman dan takwa. Para siswa dengan demikian dibiasakan untuk selalu meningkatkan iman dan takwanya dengan cara memperdalam ilmu agama dan rajin beribadah menurut ajaran agamanya. Terdapat juga konsep karsaningsun memayu hayuning bawana, yang artinya hasrat, keinginan, niat yang diarahkan untuk kesejahteraan dan keindahan alam untuk memperbaiki keadaan alam, kondisi hidup manusia, menciptakan perdamaian dan kerja sama antarsesama hingga tercipta kehidupan yang gemah ripah loh jinawi titi tentrem kerto raharjo, yaitu yang menggambarkan bumi pertiwi Indonesia akan kekayaan alamnya yang melimpah dan keadaan yang tenteram.

Kebiasaan masyarakat Dieng adalah ngendong. Ngendong mempunyai arti berkumpul di tempat saudara ataupun tetangga sambil mengobrolkan suatu hal, atau memusyawarahkan suatu hal dengan kondisi santai tetapi bermakna. Masyarakat Jawa juga mempunyai segudang konsep yang memiliki nilai dan makna yang baik, misalnya becik ketitik ala ketara, yang artinya baik dan buruk pada akhirnya akan terlihat. Nilai-nilainkonsep Jawa apabila dipahami dengan saksama, nilai-nilai konsep Jawa ini mampu menuntun masyarakat hidup berdampingan secara harmoni, selaras, dan seimbang dengan lingkungan dan kondisi yang 
terjadi. Kearifan lokal dalam lingkup ini dapat membangun karakter bangsa.

Lingkup kearifan lokal yang kedua adalah ritual dan tradisi serta makna di baliknya. Berdasarkan temuan penelitian, di masyarakat Dieng terdapat upacara ritual cukur rambut gimbal. Makna di balik upacara ritual cukur rambut gimbal adalah mengucap syukur kepada Tuhan dan memohon keselamatan untuk masyarakat Dieng khususnya dan masyarakat Indonesia umumnya. Nilai yang dapat diambil dari upacara ritual cukur rambut gimbal adalah menjaga keharmonisan hubungan manusia dengan Tuhan, manusia dengan sesama manusia, dan hubungan manusia dengan alam atau lingkungan sekitar.

Lingkup kearifan lokal yang ketiga adalah legenda dan mitos yang biasanya mengandung pesan-pesan tertentu. Berdasarkan temuan peneliti, mitos dan legenda di dataran tinggi Dieng adalah mengenai Mbah Kolodete dan sang anak berambut gimbal titisan Mbah Kolodete. Masyarakat dataran tinggi Dieng telah memercayai hal tersebut dari masa lampau. Siring berjalannya waktu sebagian masyarakat memercayai bahwa rambut gimbal adalah suatu keunikan penyakit titipan Allah yang disebabkan adanya suhu dingin, pola makan, dan kurangnya menjaga kebersihan. Masyarakat dataran tinggi Dieng masih banyak yang memercayai mitos tersebut yaitu mitos dalam pengertian titipan Mbah Kolodete. Pesan yang dapat diambil dalam mitos tersebut adalah bahwa anak berambut gimbal itu istimewa dan harus diperlakukan secara istimewa dan hati-hati agar tidak terjadi malapetaka. Dalam menghilangkan balak yang terdapat di dalam diri anak gimbal tersebut, maka harus mengadakan upacara ritual cukur rambut gimbal. Masyarakat dengan demikian, dilarang mencukur sembarangan tanpa adanya upacara ritual. Berdasarkan hasil wawancara dengan tokoh agama, upacara pemotongan rambut gimbal tidak bertentangan dengan agama yang dianut oleh masyarakat Dieng. Tahap-tahap upacara dalam hal ini terdapat nilainilai religius yang baik dan cocok dan dapat dijadikan tuntunan dalam masyarakat, sehingga kajian agama tidak dapat dilepaskan dari upacara.

$\mathrm{Hal}$ ini diperkuat dengan pendapat Rumansara (2003: 212), yang menyatakan bahwa upacara merupakan unsur yang terpenting dalam kehidupan beragama karena melalui upacara manusia dapat menyatakan hubungannya dengan penguasa yang disembah. Upacara dalam hal ini selalu mengingatkan manusia berkenaan dengan eksistensi dan hubungan masyarakat Dieng dengan lingkungan tempat mereka berada.

Hal selanjutnya adalah pengetahuan yang terhimpun pada pemimpin adat, bahwa sebagai masyarakat turun-temurun harus tetap melestarikan tradisi peninggalan leluhur. Hal ini dilakukan agar nilai-nilai tradisi tidak hilang. Berdasarkan temuan penelitian, kitab suci yang diyakini kebenarannya oleh masyarakat adalah Alquran dan sebagian meyakini Injil. Hal ini dikarenakan sebagian besar masyarakat memeluk agama Islam dan sebagian kecil lainnya adalah Kristen.

Berdasarkan temuan penelitian, cara komunitas lokal dalam memenuhi kehidupan sehari-hari adalah dengan bertani. Pertanian di dataran tinggi Dieng sangat maju dan menjadi andalan bagi masyarakat Dieng. Komoditas utama yang dihasilkan adalah kentang dan carica (gandul gunung). Berdasarkan temuan penelitian, alat/bahan untuk memenuhi kebutuhan tertentu adalah alat-alat pertanian seperti penyemprot pupuk dan cangkul. Kondisi sumber daya alam yang dimanfaatkan dalam penghidupan masyarakat sehari-hari cukup melimpah. Di dataran tinggi Dieng banyak terdapat mata air yang dimanfaatkan dalam penghidupan masyarakat. Masyarakat Dieng tidak hanya memanfaatkan saja, tetapi juga merawat dan melestarikannya.

Berdasarkan temuan penelitian dapat disimpulkan bahwa kearifan lokal masyarakat Dieng mempunyai nilai-nilai budaya yang dapat dijadikan dasar hidup bermasyarakat untuk membangun karakter bangsa. Nilai-nilai tersebut pantas dijadikan fondamen hidup karena di dalamnya terkandung aspek weruh, eling, dan ening. Weruh mengandung arti tahu tentang jati diri sebagai makhluk Tuhan, yaitu sehebathebatnya manusia tetap di bawah kendali Tuhan Yang Maha Esa. Eling artinya manusia itu tidak boleh lupa bahwa dirinya kelak akan kembali kepada Tuhan yang telah menciptakan manusia. Ening berarti manusia wajib untuk 
menyempatkan diri mengingat Tuhan dengan cara berdoa. Dapat disimpulkan bahwa terdapat relevansi antara kearifan lokal dan karakter bangsa. Kearifan lokal dengan demikian dapat membangun karakter bangsa. Hal ini sependapat dengan Wagiran (2012:329), yang menyatakan bahwa nilai-nilai kearifan lokal bukanlah penghambat pada era global, namun menjadi kekuatan yang luar biasa dalam membangun karakter bangsa.

\section{Simpulan}

Pembangunan karakter bangsa dan pendidikan memiliki andil untuk memajukan agar menjadi bangsa yang maju dengan sumber daya manusia yang berilmu, berwawasan kebangsaan, dan berkarakter. Karakter merupakan hal yang sangat penting dalam kehidupan berbangsa dan bernegara sehingga hilangnya karakter menyebabkan akan hilangnya generasi penerus bangsa. Tujuan pembangunan karakter bangsa adalah untuk memperkuat jati diri bangsa, untuk menjaga keutuhan NKRI, untuk membentuk masyarakat Indonesia yang berakhlak mulia, dan membentuk bangsa yang bermartabat. Bangsa yang besar adalah bangsa yang memiliki karakter berasal dari nilainilai budaya masyarakatnya.

Nilai kearifan lokal mempunyai relevansi dengan pembangunan karakter bangsa. Oleh karena itu, upaya menggali nilai kearifan lokal merupakan langkah yang strategis dalam pembangunan karakter bangsa. Kearifan lokal merupakan nilai yang berlaku dan diyakini dalam suatu masyarakat serta menjadi acuan bertingkah laku dalam kehidupan sehari-hari. Kearifan lokal dalam masyarakat dapat ditemui dalam semboyan, konsep, pepatah, nyanyian, kitab-kitab kuno, tradisi, dan cara masyarakat lokal memenuhi kebutuhan hidupnya.

\section{Ucapan Terima Kasih}

Penulis mengucapkan terima kasih kepada Prof. Dr. Sapriya, M.Ed. sebagai Ketua Departemen Pendidikan Kewarganegaraan, Sekolah Pascasarjana Universitas Pendidikan Indonesia.

\section{Kepustakaan}

Abidin, Y. Z., \& Beni, A. S. 2014. Pengantar Sistem Sosial Budaya Di Indonesia. Bandung: CV Pustaka Setia.

Budimansyah, D. 2010. Penguatan Pendidikan Kewarganegaraan untuk Membangun Karakter Bangsa. Bandung: Widya Aksara Press.

Dahliani. 2015. "Local Wisdom in Built Environment in Globalization Era”. International Journal of Education and Research, 6(3), 157-166.

Darahim, A. 2015. Membentuk Jati Diri \& Karakter Anak Bangsa. Jakarta: Institut Pembelajaran Gelar Hidup.

Fahrianoor. 2013. "The Practice of Local Wisdom of Dayak People in Forest Conservation in South Kalimantan". Indonesian Journal of Wetlands Environmental Management, 1(1), 37-46.

Gustiningrum, PW dan Idrus Affandi. 2016. "Memaknai Nilai Kesenian Kuda Renggong dalam Upaya Melestarikan Budaya Daerah di Kabupten Sumedang ". Journal of Urban Society's Art. 3(1), 20-27

Koentjaraningrat. 1990. Pengantar Ilmu Antropologi. Jakarta: PT Rineka Cipta.

Lickona, T. 2013. Educating for Character: How Our Schools Can Teach Respect and Responsibility. Jakarta: PT Bumi Aksara.

Nurgiyantoro, B. 2011. "Wayang Dan Pengembangan Karakter Bangsa”. Jurnal Pendidikan Karakter, 1(1), 18-34.

Rumansara, E. H. 2003. “Transformasi Upacara Adat Papua: Wor dalam Lingkungan Hidup Orang Biak". Jurnal Humaniora, 2(15), 212223.

Sukatno, A. 2003. "Seni Pertunjukan Wayang Ruwatan Kajian Fungsi dan Makna”. Harmonia Jurnal Pengetahuan Dan Pemikiran Seni, 1(1), 1-16.

Sukirno. 2009. "Hubungan Wayang Kulit dan Kehidupan Sosial Masyarakat Jawa". Brikolase, 1(1), 16-32.

Sulasman, \& Gumilar. 2013. Teori-Teori Kebudayaan: dari Teori Hingga Aplikasi. Bandung: Pustaka Setia. 
Suparlan, H. 2014. Filsafat Pendidikan Ki Hadjar Dewantara dan Sumbangannya bagi Pendidikan Indonesia. Jurnal Filsafat, 1(25), $1-19$.

Tampubolon, A dan Cecep Darmawan. 2016. "Fashion Budaya Nasional dalam Konteks Wawasan Kebangsaan: Studi Kasus pada Jember Fashion Carnaval". Journal of Urban Society's Art, 3(1), 11-19.
Wagiran. 2012. "Pengembangan Karakter Berbasis Kearifan Lokal Hamemayu Hayuning Bawana (Identifikasi Nilai-nilai Karakter Berbasis Budaya)". Jurnal Pendidikan Karakter, 3, 329-339.

Yunus, R. 2014. Nilai-Nilai Kearifan Lokal (Local Genius) Sebagai Penguat Karakter Bangsa Studi Empiris tentang Huyula. Yogyakarta: Deepublish. 